\title{
MSME's Acceleration Strategy Based on Sharia Bank Financial Performance in Indonesia
}

\author{
1 TASYA ASPIRANTI, 2 IMA AMALIAH \\ ${ }_{1}^{1}$ Managemen Department, Universitas Islam Bandung, Jl. Tamansari No. 1 Bandung, Indonesia \\ Economics Department, Universitas Islam Bandung, Jl. Tamansari No. 1 Bandung, Indonesia \\ email: 19ad_tasya@yahoo.com, 2amalia.razi@gmail.com
}

\begin{abstract}
Sharia (Islamic law-compliant) bank financing has a crucial role to accelerate MSMEs (UMKM), but the market share is still below $5 \%$. The purpose of this study is to identify and analyze the effect of financial performance on Sharia bank financing for the MSMEs' sector and Msme's acceleration strategy in Indonesia for the period of 20052017. The research method uses descriptive \& verification analysis and SWOT analysis. This study also uses OLS method and SWOT matrix by secondary data published by the OJK. The results of the study show MSMEs' financing in Sharia banks is significantly influenced by Capital Adequacy Ratio (CAR), Non-Performing Finance (NPF), Return on Assets (ROA), Return on Equity (ROE), and Operating Expense Ratio (OER) to Operating Income. Accelerating Sharia bank financing for MSMEs through risk minimization (return maximization) and cost efficiency is purposed to solve low efficiency (OER), high nonperforming financing (NPF), adequacy capital fluctuation (CAR), and low return of assets and equity (ROA, ROE).
\end{abstract}

Keywords: sharia banks, acceleration strategy, financial performance

\section{Introduction}

Micro, Small and Medium Enterprises (MSMEs) have a strategic role in the economy and are the backbone of socio-economic development. MSMEs provide job opportunities for educated and uneducated workers to be the engines of economic growth, encourage economic diversification, and reduce poverty and job shortages (Al Balushi, Locke, \& Boulanouar (2019). However, behind this strategic role, there are a number of very classic problems faced by MSMEs such as capital, marketing, availability of raw materials, management, etc. The presence of Sharia (Islamic law-compliant) commercial banks more or less provides a solution for capital problems faced by MSMEs. Financing with various contract schemes can be utilized by MSMEs to accelerate growth and expand the business.

However, the growth of Islamic banking seems to have stagnated against the national banking system even though the development of Sharia banks in Indonesia is conducive in terms of the composition of Muslim population in Indonesia, support from the government in the form of Sharia Banking Law No. 21 of 2008, the existence of the National Sharia Board and Sharia Supervisory Board (Huda, 2009: 208 in Nurhasanah, 2013), and the existence of Sharia service units (office channeling).

The market share performance of Sharia banking tends to be stagnant compared to the financial performance of conventional commercial banks. The scale of Sharia banking operation is still very limited so that the operating expense ratio to operating income (BOPO) of Sharia bank is greater than conventional commercial banks. In addition, the limited capital of Sharia banking makes Sharia banks have to be more careful in allocating their capital, which will have an effect on the low ability to gain profits and low Capital Adequacy Ratio. The high risk faced by Sharia banks will have implications for the low level of profitability that can be collected by Sharia banks. Therefore, they will be more careful in allocating their assets that have an impact on the less than optimal performance

Received: 2019-03-08, Revised: 2019-08-04, Accepted: 2019-12-23 
of Sharia banks as indicated by the low Return on Assets (ROA). ROA of Sharia banks is below $1 \%$, while ROA of conventional banks is above 1.5\% (Moin, 2008). Capital limitations and third party funds owned by Sharia banks have implications for the lack of optimal financing for MSMEs sector. Therefore, the researchers want to dig further information about the influence of financial performance on Sharia bank financing for MSME sector as well as MSMEs acceleration strategy based on Sharia bank financing in Indonesia for the period of 2005-2017.

Sharia banking has a very strategic role (Setiawan, 2016) in the economy, namely a). As an intermediary institution that connects the parties which have excess funds to those who need funds; b). Sharia banking as an agent of development in which the funds collected by Sharia banks will be transferred to those who carry out production and investment activities; c). Sharia banking as an agent of trust or an institution that sells services; d). Sharia banks connect Bank Indonesia's monetary policy to the real sector; e). Sharia banks can influence money supply through financing distribution (Mishkin, 2008).

This very strategic role can be played optimally by Sharia banking through various financing activities. According to Law No. 21 of 2008 concerning Sharia banking, financing is the provision of funds or bills equivalent to that in the form of a). Profit-sharing transactions in the form of mudharabah (partnership agreement) and musyarakah/musharakah (joint enterprise); b) Lease transactions in the form of ijarah or lease purchases in the form of ijarah muntahiya bittamlik; c) Buying and selling transactions in the form of murabahah, salam (sale contract), and istishna (contract/participation) receivables; d) Loan and loan transactions in the form of qardh receivables; e) Service leases in the form of ijarah for multi-service transactions based on agreements or agreements between Sharia Banks and/or UUS (Sharia Business Unit) and other parties (Bank Indonesia, 2018).

There are many financing schemes that can be used by MSMEs to finance their business activities. Although Sharia banking offers various financing schemes, there are only three types that quite popular to the public, namely sale and purchase agreement (Murabahah) and the cooperation agreement (mudharabah and musyarakah). The ability of a bank to channel its financing is very dependent on its soundness position or financial performance. The assessment of bank soundness is a qualitative assessment of various aspects that affect the condition or performance of a bank, namely through the assessment of capital adequacy, asset quality, management quality, earnings conditions, liquidity conditions, and sensitivity to market risk.

Results information on a bank's soundness evaluation can be used to determine future business strategies and the means for determining and implementing bank supervision strategies by Bank Indonesia. The classification of bank soundness according to the Financial Services Authority Regulation Number 4 /POJK.03/2016 (OJK, 2016) is divided into four categories: sound, adequately sound, less sound, and unsound. Sharia bank financial ratio variables used in this study represent the level of capital adequacy (CAR), asset quality (NPF), level of profitability (ROA, ROE) and operational efficiency (BOPO).

CAR is a capital adequacy ratio showing the ability of banks to provide funds used to overcome the possibility of loss risk. This ratio is important since the adequacy of CAR at the safe limit (minimum of $8 \%$ ) means it also protects customers and maintains overall financial system stability. The greater the value of CAR reflects the better ability of banks in dealing with the possibility of loss risk. A high value of CAR shows that banks have large capital buffers to anticipate losses (OJK, 2018). Banks with a high value of CAR will have a greater ability to channel the financing.

NPF (Non-Performing Financing) according to Maidalena (2014) is a debtor or group of debtors in the collectibility category $3,4,5$ out of 5 financing categories, i.e. debtors who are substandard, doubtful, and bad. Changes in the classification of financing from smooth to non-performing gradually occur through a process of decreasing the quality of financing. NPF can demonstrate the ability of a bank in managing financing problems. It is the higher the NPF ratio, the worse the quality of bank financing which causes greater financing problems. According to Financial Services Authority Regulation Number 4/POJK.03/2016, the maximum NPF owned by banks is $5 \%$ (OJK, 2016).

ROA is a ratio that measures the ability of banks to generate profit or profitability 
by comparing net income with resources or total assets owned. The function of ROA is to determine how effectively banks use their assets to generate income. It is the greater the value of ROA, the better the ability of banks to generate profits. ROA can describe the level of effectiveness of asset management to net income obtained by banks. ROA is called sound if its value is greater than $1.5 \%$. The greater the value of ROA, the higher the profit generated which means the greater the financing that can be channeled by banks.

ROE is the amount of return from net income to equity and is expressed in a percent. ROE is used to measure the ability of an issuer to generate profits with equity capital that has been invested by shareholders. ROE is very attractive to candidates as well as shareholders and management because it is a measure or indicator for shareholder creation value. This means that the higher the ROE, the higher the value of the company. ROE is an indicator to measure the ability of banks to obtain net income and is calculated based on net income (net profit after tax) of own capital. ROE is sound if the value is greater than $1.5 \%$ (OJK, 2016).

BOPO/OER is a ratio illustrating the efficiency of banks in conducting their operational activities. Operational expenditure is interest expense given to customers while operating income is interest earned from customers. The higher BOPO indicates that the bank as a whole is inefficient. Bank Indonesia will usually call banks that have a BOPO ratio close to 90 . A soundness BOPO ratio ranges from 60-70.

Those financial ratios aforementioned are very significant indicators for the bank soundness that will have implications for the ability of banks to distribute financing. Financing is one of the main sources of Sharia bank revenue that comes from revenue sharing and margin. The higher the bank's revenue from profit sharing and margins the greater the bank's ability to generate profits. Therefore, banks will carry out various strategies to win the competition in business activities.

The development of information technology has led to increasingly intense competition in the banking industry. To survive and win the competition, Sharia banks have to review their competitive strategies. Sukanto (2003), Hunger and Wheelen (2001: $16)$, David (2009: 18) say that strategy is a shared tool and a foundation for long-term goals that are translated into various company policies to be further outlined in activities programs that contain strategies need to be taken in accordance with the situation and conditions, as well as follow-up programs and resource priorities (Rangkuti, 1998). The strategy will maximize competitive advantage and minimize the limitations of the institution.

Hunger and Wheelen (2001: 22) state there are four things should be considered in formulating strategies, namely mission, goals, strategies, and policies. Meanwhile, according to Wahyudi (1996: 99), the process of making strategy consists of four elements: (a) Identification of strategic problems faced by the organization; (b) Development of alternative strategies available by considering generic strategies and their variations; (c) Evaluation of each alternative; (d) Determination or selection of the best strategies out of various alternatives available.

\section{Research Methodology}

To answer the research problem, there are two approaches used namely descriptive quantitative and verification as well as SWOT analysis. Whereas, the method in developing is a literature survey either of data published by the Financial Services Authority (OJK) or various bibliography references from books and journals that contain empirical studies from previous research.

The data used is the 2005-2017 annual data of total Sharia bank financing for the MSMEs sector, as well as CAR, NPF, ROA, $R O E$, and BOPO financial ratios. The research stage begins with a descriptive analysis through quantitative data description of each independent variable, i.e. CAR, NPF, ROA, ROE and BOPO, and the total dependent variable of Sharia bank financing for the MSME sector in order to obtain data profiles of independent and dependent variables.

To test the effect, the Ordinary Least Squares (OLS) analysis method is performed using the Eviews Version 8 software. Before the analysis, a classic assumption test is undertaken, namely autocorrelation, heteroscedasticity, normality, and linearity to make sure that the model is BLUE (Best Linear Unbiased Estimator) (Gujarati, 2009). The next step is to map the MSMEs acceleration strategy using a four-quadrant matrix (SWOT) analysis derived from information on strengths, opportunities, weaknesses, and 
threats faced by Sharia commercial banks in expediting financing for MSMEs. The existing condition of Sharia banks can be synthesized from the profile of strength, opportunities, weaknesses, and threats as input to analyze the proper strategy in overcoming various problems encountered and to take advantage of various opportunities.

\section{Results and Discussion}

The effect of financial performance on MSMEs Sharia bank financing can be found out through the estimation of a model using the Eviews 8. In the initial stage, classical assumptions will be tested to ensure that the model is free from classic assumptions or BLUE problems (Gujarati, 2009). Table 2 is a summary of the test results

\section{Illustration of the Research Result on a Comprehensive Model}

The above table shows that Sharia bank financing estimation model for MSMEs in Indonesia is free from classical assumption problems (heteroscedastic problems, autocorrelation, normality, and linearity), which indicates that the model is BLUE. Hence, the estimation model can be used for further analysis. Based on the model estimation results, we can identify the MSME Financing Model at Sharia Commercial Banks in Indonesia as in table 1

Table 1

Estimation Result of Financial Sharia Commercial Banks

\begin{tabular}{lcc}
\hline \multicolumn{1}{c}{ Variable } & Coefisien & T statistic \\
\hline Constanta & -1019.43 & -6.91 \\
CAR & 8.092 & 3.091 \\
(NPF $(-1$ & -6.043 & -1.879 \\
ROA & 101.69 & 5.930 \\
(ROE $(-2$ & -3.38 & -6.510 \\
BOPO & 11.36 & 8.262 \\
\hline
\end{tabular}

$\mathrm{R}^{2}=0926$

Note:

the probability value for the CAR variable is 0.02 with a coefficient value of 8.092 . This means that at a 1 percent confidence level, CAR has a statistically significant positive effect on Sharia commercial bank financing for MSMEs in Indonesia.

The magnitude of CAR effect on Sharia bank financing for MSMEs in Indonesia is 8,092, which means when the CAR value rises by 1 percent, financing at Sharia commercial banks for MSMEs would increase by 8,092 billion Rupiah. The greater the CAR value, the greater the ability of Sharia banks to disburse their funds of financing for MSMEs either in murabahah, mudharabah or musyarakah schemes. CAR value can be an indicator that a bank has already had sufficient capital and reserves to carry various risks that may occur (Rivai, 2013:465). For a bank, the capital functions to reduce risk. This is based on three ideas: capital can be a buffer for banks to absorb losses and remain solvent, capital gives the banks access to financial markets, and capital limits bank growth and risk-taking. (Koch \& MacDonald, 2014).

Furthermore, Taswan (2013:139) adds that capital functions to finance business activities of banks and adhere to the regulations set by the monetary authority. Muhammad (2011) mentions that Sharia bank capital sources consist of core capital and quasi-equity. The core capital functions as a buffer and absorbent of losses as well as protecting the interests of deposit account holders (wadiah) and loans (qard), while quasi-equity can only bear the risk of assets financed by funds from the profit-sharing account itself (Andhika \& Suprayogi, 2017).

From data development, the CAR value of Sharia banking is more than $14 \%$, which means it is quite sound but fluctuates. The fluctuation in the CAR value of Sharia banking has implications for the unstable availability of murabahah, mudharabah and musyarakah financing schemes for the public. Thus, funding for MSMEs included in those schemes is still unsustainable in terms of the quantity of funding. Sharia banks are still at risk in their solvency or their ability to anticipate capital shortages in the long run and have not been able to guarantee the ease or sustainability of access to funding for MSMEs. This happens, especially, when there is a change in monetary regulation. The very dynamic monetary regulations in Indonesia as an effort to stabilize the financial market and the real sector will in turn risk the continuity of funding to MSMEs through Sharia Banks if the availability of capital is not increased until it comes to the position of having a better amount than now.

The probability value of NPF variable is 0.11 with a coefficient value of -6.043 , meaning that at an $89 \%$ confidence level, the NPF statistically influences financing at Sharia banks significantly. NPF is significant in lag 1 (NPF-1), meaning that when there is an increase in non-performing financing of the previous year, Sharia banks will reduce the disbursement of financing in the current 
year. This indicates that Sharia banks are quite anticipative toward the declining of financing quality. Sharia banks are quite careful about non-performing financing which will have implications for the ability of Sharia to collect revenue from profit sharing and margins. According to Muhammad (2011), the source of non-performing financing is that banks are too easy to provide financing or make investments since there is a guide to take advantage of excess liquidity so that the valuation of financing becomes inaccurate in anticipating various possible business risks to be financed and external conditions such as economic crisis and inflation (Arifin, 2012).

According to Gup and Kolari (2005: 68); Rafsanjani, Amin \& Mujib, 2017), Ioan quality can be seen from the number of writeoffs and Non-Performing Loans (Financing). The magnitude of NPF on Sharia commercial banks almost touch the 5\% figure and is far greater than NPF of conventional banks. This shows the quality of Sharia bank financing is relatively risky compared to conventional banks. The high value of NPF cannot be separated from the limited CAR condition. Funding for MSMEs becomes more limited due to the high NPF since MSMEs operate in the real sector with quite high risks. Unstable economic conditions have an impact on the high risk of the real sector, thus the behavior of Sharia banks will be more prudent to MSME funding.

The probability value of ROA variable is 0.00 with a positive coefficient value of 101.69. It means when ROA value rises by $1 \%$, funding for MSMEs in Sharia commercial banks will increase by 101.690 billion rupiahs. This finding is consistent with the hypothesis stating that the higher the ROA, the greater the financing that can be channeled by Sharia commercial banks. The greater the ROA of a bank, the greater the level of profit achieved, and the better the bank's position in terms of asset use (Gumanti, 2011) so that the ability of banks to channel funds also increases. The value of ROA is determined by factors of internal and external environment (Ernayani, Moorcy, \& Sukimin, 2018). The most significant external factor affecting ROA of Sharia commercial banks is the BI Rate (Ernayani, Moorcy, \& Sukimin, 2018); Tinton (2015); Alim (2014); Swandayani \& Kusumaningtias,2012) since the increase in BI rate will be followed by an increase in interest rates of conventional bank deposit so that the collection of funds and financing in Sharia banks will decline and impact on the degenerate of profit performance (ROA). If the fund collection decreases due to the BI rate, Sharia banks need to find alternative investment portfolios outside the real sector to increase ROA. Optimal investment portfolios encourage the increase in assets to raise MSME funding in Indonesia.

The estimation result shows the probability value for t-statistic of the ROE lag (2) variable is 0.00 with a coefficient value of 3.38. It means the ROE of two years earlier has statistically had a very significant positive effect on MSME financing at Sharia commercial banks in Indonesia. The magnitude of the effect of lag 2 ROE on financing is 3.38. When ROE of two years earlier rose by $1 \%$, financing in Sharia banks would increase by 3.38 billion rupiahs. In this case, it is possible for banks not to distribute dividends to shareholders so that an increase in profit enhances Sharia commercial bank financing. This finding is in line with research by Russely (2014) who found a positive relationship between profit performance and financing. It means that the higher the ROE, the better the productivity of the bank's own capital to make a profit. In addition, ROE is also a measure of the rate of return expected by bank shareholders (Rose, 2012). ROE measures net income after tax with own capital. ROE provides a measure of the management effectiveness level of a

Table 2

Summary of Classical Assumption Testing Results for the MSME Financing Model of Sharia Commercial Banks in Indonesia

\begin{tabular}{|c|c|c|c|}
\hline No & Type of Test & Statistical Magnitudes & Conclusion \\
\hline 1 & Heteroscedastic Test & Prob. Chi-Square $(1)=0.368$ & $\begin{array}{l}0.368>0.05 \text { (There is no heteroscedastic } \\
\text { problem in the Estimation Model) }\end{array}$ \\
\hline 2 & Autocorrelation Test & Prob. Chi-Square $(1)=0.0205$ & $\begin{array}{l}0.0205>0.01 \text { (There is no autocorrelation } \\
\text { problem in the estimation model) }\end{array}$ \\
\hline 3 & Normality test & Prob. Jarque Bera $=0.6880$ & $\begin{array}{l}0.6880>0.05 \text { (Residuals are normally } \\
\text { distributed) }\end{array}$ \\
\hline 4 & Linearity Test & Prob. F Stat. $=0.8248$ & $0.8248>0.225$ (Residuals are linear) \\
\hline
\end{tabular}

Source: Processed from secondary data using Eviews Software 
bank as indicated by the profits generated from sales and investment income. The higher profit shows the more efficient management of a bank because bank profitability shows the ability to generate profits exceeding the costs required (Alhassan, 2015) that depend on the capital owned by the bank (Alshatti, 2015). Funding for MSMEs will increase if the ROE of Sharia Banks rises. Therefore, increasing Sharia Commercial Bank product sales and investment income should be the focus of Sharia Commercial Bank targets in Indonesia

The last variable influencing Sharia commercial bank financing is BOPO. The estimation results show that the opportunity value of $\mathrm{t}$ - statistic is 0.00 with a coefficient value of 11.33. It means that BOPO has a statistically significant positive effect on the financing of Sharia commercial banks in Indonesia. The magnitude of BOPO's influence on Sharia Commercial bank financing to MSMEs is 11.33 . That is, an increase in BOPO of $1 \%$ will be followed by an increase in Sharia commercial bank financing for MSMEs by 11.33 billion rupiahs. The direction of the relationship between BOPO and financing is not in accordance with the theory since it says that the larger the BOPO then the Sharia commercial bank financing will be smaller. Sharia banking in Indonesia is still inefficient in collecting funds, in which the incoming funds are expensive funds (deposits) so that the BOPO at Sharia banks is still above 70. The average BOPO of Sharia banks in Indonesia is at 90, which is greater than BOPO of conventional bank. The ratio of operational costs is used to measure the level of efficiency and the ability of banks to operate (Wijaya \& Sihombing, 2015).

The lower the BOPO means the more efficient the bank is in controlling its operational costs. Cost efficiency will create greater profits (Juliana \& Mulazid, 2017). According to Bank Indonesia, there are four things determine BOPO value of a bank. First, the scale of a bank's industry; second, the cost of funds that will determine the cost structure of banks; third, risk premium; and fourth, bank lending rates (Wibawa, 2013). However, this is a business opportunity for Sharia commercial banks due to the very large number of MSMEs in Indonesia. The problem of MSME funding inefficiency due to the small scale of operations can be overcome through MSMEs collective funding by Sharia banks. Collective funding, in addition to minimizing the risk of non-performing loan is also streamlining operational costs through costs jointly borne among MSMEs groups.

\section{MSME Financing Acceleration Strategy Viewed from Financial Ratio}

By referring to the above estimation results and data exploration of financing for MSMEs from OJK (Financial Authority Services) as well as previous studies, the Sharia banking financing acceleration strategy for MSMEs is mapped in Table 2.

There are two crucial grand strategies that must be considered by Islamic Commercial Banks in an effort to accelerate financing for MSMEs, namely risk management and cost efficiency strategies. Risk Management Strategies include a) Risk minimization that can be carried out through several programs, namely 1) Early Warning System is carried out to detect the beginning of non-performing which is counterbalanced by the flexibility of product offering through considering the segmentation of Sharia bank offerings in the real sector; 2) Collection Department is carried out through mapping potential market share, maintaining customers who have good records, working under very tight targets, and willing to expand into areas that have not yet been reached by banking services; 3) Tight Cost of Funds Calculation, which is calculating the cost of funds strictly as a prudent attempt in receiving third-party funds; 4) Assessment of Bank's Management of Financing Risk. The management of a Sharia bank is periodically responsible for reviewing the financing risk strategies that have been and are being carried out in the form of tolerance of the risk level of Sharia Bank financing. b). Sharia banks need to build an Effective Workout Program that involves internal management elements which collectively formulate strategies to resolve various problematic financing through: a) Maximization of Returns conducted through programs, namely 1) Resilience, an effort to build financing resilience indicated by timeliness and ability of customers in fulfilling financing payment obligations in accordance with the agreement with Sharia Bank. 2) Product Development through learning the behavior of new market segments and striving to offer excellent service for customers (Customer Service Champions).

\section{Operational Cost Efficiency Strategy}

To deal with such a situation, a long- 
Table 2

The SWOT Matrix of Financing Acceleration for MSMEs Viewed from Financial

\begin{tabular}{|c|c|}
\hline $\begin{array}{l}\text { Strength } \\
\text { a. Indonesia's Muslim population of } 90 \% \\
\text { is a captive market for Sharia bank } \\
\text { financing } \\
\text { b. Sharia banks have a clear legal framework } \\
\text { c. Sharia banks have a real commitment to } \\
\text { financing as indicated by the high value } \\
\text { of FDR (More than } 90 \% \text { ) } \\
\text { d. The increased number of Sharia bank } \\
\text { service offices in many cities to improve } \\
\text { Sharia bank financing opportunities }\end{array}$ & $\begin{array}{l}\text { Weakness } \\
\text { a. Funding is still focused on the sale and purchase } \\
\text { agreement and the small proportion of funding for } \\
\text { cooperation } \\
\text { b. The largest proportion of financing is for consumption } \\
\text { and there is very little funding for the real sector } \\
\text { investment } \\
\text { c. The still very limited proportion of financing for } \\
\text { medium and large businesses } \\
\text { d. The still very limited proportion of funding for tradable } \\
\text { sector (agriculture, industry, and trade) } \\
\text { e. The high BOPO reflects the lack of efficiency of Sharia } \\
\text { banks in raising funds } \\
\text { f. Sharia banks have the tend-to-increase NPF value } \\
\text { g. The high mismatch risk where short-term funds are } \\
\text { used for long-term financing ( } 1 \text {-month deposit ratio } \\
\text { is above } 60 \% \text { ) } \\
\text { h. Capital adequacy (CAR) fluctuates every year, even } \\
\text { though the value is above } 14 \% \\
\text { i. ROA value is still very low (less than } 1 \% \text { ) } \\
\text { j. The ability of Sharia banks to generate profits using } \\
\text { their own capital (ROE) continues to decline every } \\
\text { year }\end{array}$ \\
\hline $\begin{array}{l}\text { Opportunities } \\
\text { a. MSMEs growth continues to increase } \\
\text { related to fintech adoption } \\
\text { b. The increased of public trust can be seen } \\
\text { from the increase in third-party funds } \\
\text { (DPK) } \\
\text { c. The development of fintech that can be } \\
\text { adopted by Sharia banking thus opens } \\
\text { up opportunities for peer to peer lending } \\
\text { d. Government regulations regarding the } \\
\text { investment of hajj funds in Sharia banks } \\
\text { in the form of deposits to strengthen the } \\
\text { position of Sharia bank asset } \\
\text { e. Increase the enthusiasm of young } \\
\text { Muslim entrepreneurs through business } \\
\text { start-ups }\end{array}$ & $\begin{array}{l}\text { Threats } \\
\text { a. The slowdown of global economic growth has an } \\
\text { impact on slowing down national economic grow } \\
\text { b. Rupiah depreciation } \\
\text { c. The increase in foreign interest rates } \\
\text { d. The low switching rate (transfer of conventional } \\
\text { customers to Sharia) }\end{array}$ \\
\hline
\end{tabular}

term strategy using a systems and process approach needs to be undertaken by Sharia banks through programs: a) Streamlining management is done through clarity of roles and responsibilities for each management position; b) Rationalizing the portfolio is carried out in a more selective way to conduct investment portfolios that not only minimize the risk but also have the potential to maximize returns which have an effect on operational costs; c) Outsourcing of operational personnel which will have an impact on lowering fixed costs and more controlled operating costs; 4) The use of information technology to streamline operational processes, maximize every opportunity, and develop flexible products in accordance with the characteristics of the Sharia Bank real sector market segment; 5)
MSMEs collective funding so that the risks and costs are shared by the MSME groups.

\section{Conclusions}

First, Sharia commercial bank financing for MSMEs is strongly influenced by financial performance consisting of CAR, NPF $(-1)$, ROA, ROE (-2) and BOPO. A variable with an enormous influence on financing is ROA. NPF and BOPO movements must be considered more seriously by Sharia banks remembering these two variables work the opposite way against CAR, ROA, and ROE. Second, the strategy for accelerating Sharia bank financing can be done in two ways, namely how to minimize risk (maximize returns) and operational cost-efficiency. Risk minimization can be done through 
an early warning system, collection data department, collective funding, portfolio investment diagnosis and analysis, and cost of fund calculations. While operational cost efficiency can be done through streamlining management, cost rationalization, labor outsourcing, MSMEs collective funding, and the use of labor. To accelerate the financing of Sharia banks for MSMEs, the MSME itself has to carry out internal reforms in the form of reforming business management, product standardization, adoption of online marketing and expansion of cooperation networks in the procurement of inputs, production processes, and distribution.

\section{References}

Alhassan, A. L. (2015). Income diversification and bank efficiency in an emerging market. Managerial Finance, 41(12), 1318-1335.

Alshatti, A. S. (2015). The effect of credit risk management on financial performance of the Jordanian commercial banks. Investment Management and Financial Innovations, 12(1), 338-345.

Al Balushi, Y., Locke, S., \& Boulanouar, Z. (2019). Determinants of the decision to adopt Islamic finance: evidence from Oman. ISRA International Journal of Islamic Finance.

Andhika, Y. D., \& Suprayogi, N. (2017). Faktor-faktor yang mempengaruhi Capital Adequacy Ratio (CAR) bank umum Syariah di Indonesia. Jurnal Ekonomi Syariah Teori Dan Terapan, 4(4), 312.

Alim, S. (2014). Analisis Pengaruh Inflasi dan BI Rate Terhadap Return on Assets (ROA) Bank Syariah di Indonesia. Jurnal Ekonomi Modernisasi, 10(3), 201-220.

Arifin, Z. (2012). Dasar-dasar manajemen bank syariah. Pustaka Alfabet

Bank Indonesia. (2018).Undang-undang No. 8 tahun 2008 tentang Perbankan Syariah. https://www.bi.go.id/id/perbankan/ syariah/Documents/UU_21_08_ Syariah.pdf

David, F. R. (2009). Manajemen strategis konsep. Salemba Empat.

Ernayani, R., Moorcy, N. H., \& Sukimin, S. (2018). Faktor-Faktor Yang Mempengaruhi Return On Assets (Studi Pada Bank Umum Syariah Di Indonesia Periode 20112016). UNEJ e-Proceeding, 284-293.

Gujarati, DN dan Porter, D.J. (2009). DasarDasar Ekonometrika.Salemba Empat.

Gumanti, T. A. (2011). Manajemen Investasi:
Konsep, Teori, dan Aplikasi. Jakarta: Mitra Wacana Media.

Gup, B. E., \& Kolari, J. W. (2005). Commercial banking: The management of risk. John Wiley \& Sons Incorporated.

Hunger, J. D., \& Wheelen, T. L. (2001). Manajemen strategis (Julianto Agung, Trans). Yogyakarta: Andi.

Juliana, S., \& Mulazid, A. S. (2017). Analisa Pengaruh BOPO, Kecukupan Modal, Pembiayaan Bermasalah, Bagi Hasil Dan Profitabilitas Terhadap Simpanan Mudharabah Pada Bank Umum Syariah periode 2011-2015. Li Falah: Jurnal Studi Ekonomi dan Bisnis Islam, 2(1), 24-45.

Koch, T. W., \& MacDonald, S. S. (2014). Bank management. Nelson Education.

Maidalena, M. (2014). Analisis Faktor Non Performing Financing (NPF) pada Industri Perbankan Syariah. HUMAN FALAH: Jurnal Ekonomi dan Bisnis Islam, 1(1), 127-138.

Mishkin, F. S. (2008). Ekonomi Uang, Perbankan, dan Pasar Keuangan. Salemba Empat.

Moin, M. S. (2008). Performance of Islamic banking and conventional banking in Pakistan: a comparative study.

Muhammad. (2011). Manajemen Bank Syariah.Unit Penerbitan Dan Pencetakan Sekolah Tinggi Ilmu Manajemen YKPN.

Nurhasanah, N. (2013). Pengawasan Islam dalam operasional lembaga keuangan syariah. MIMBAR: Jurnal Sosial dan Pembangunan, 29(1), 11-18.

OJK (2016).Statistik Perbankan Syariah. Otoritas Jasa Keuangan

OJK (2018).Statistik Perbankan Syariah. Otoritas Jasa Keuangan

OJK (2016). Peraturan Otoritas Jasa Keuangan Nomor 4 /POJK.03/2016.Otoritas Jasa Keuangan

Rangkuti, F. (1998). Analisis SWOT Teknik Membedah Kasus Bisnis. Gramedia Pustaka Utama.

Rafsanjani, H., Amin, R., \& Mujib, A. (2017). Faktor-faktor yang Mempengaruhi NonPerforming Financing. Jurnal Masharif alSyariah: Jurnal Ekonomi dan Perbankan Syariah, 2(2).

Sukanto, R. (2003). Manajemen Strategi.

Rivai, V. (2013). Islamic Risk Management for Islamic Bank. Gramedia Pustaka Utama.

Rose, P. S., \& Hudgins, S. C. (2012). Bank management \& financial services. McGrawHill Education.

Russely, B. Shaw.(2014). Profit Loss Sharing on profitability islamic's bank. International Journal of Islamic Financial Services, 2(4), 120-165. 
Setiawan, I. (2016). Role of Islamic Banking and Conventional Against Poverty with The Dual Banking System. Mimbar: Jurnal Sosial dan Pembangunan, 32(2), 353-361.

Swandayani, D. M., \& Kusumaningtias, R. (2012). Pengaruh inflasi, suku bunga, nilai tukar valas dan jumlah uang beredar terhadap profitabilitas pada perbankan syariah di Indonesia periode 20052009. AKRUAL: Jurnal Akuntansi, 3(2), 147-166.

Taswan. (2013). Akuntansi Perbankan: Transaksi dalam Valuta Rupiah.UPP STIM YKPN

Tinton Saputra, A. (2015). Pengaruh Variabel
Makroekonomi Terhadap Profitabilitas Perbankan Syariah Di Indonesia Periode 2010-2013 (Doctoral dissertation, Universitas Muhammadiyah Surakarta).

Wahyudi, A. S. (1996). Manajemen strategik: pengantar proses berpikir strategik. Jakarta: Binarupa Aksara.

Wibawa, A. A. (2013).Empat hal yang mempengaruhi beban operasional bank. (https://keuangan.kontan.co.id)

Wijaya, R. D., \& Sihombing, P. (2015). Determinan Kinerja Profitabilitas Bank (Studi Kasus Bank yang Terdaftar di Kompas 100-BEI Tahun 2009-2012). Journal of Business Strategy and Execution, 7 (2), 206-235. 